has still not been established with certainty, also exhibit these characteristic absorption frequencies. On the basis of these observations the association of the $820 \mathrm{~cm}^{-1}$ band with the 6.0 -sulphate position in the monosulphate esters of glucose, galactose and $\mathrm{N}$-acetylglucosamine may be postulated. By analogy, the location of the sulphate group on position 6 of $\mathrm{N}$-acetylgalactosamine monosulphate, for which som 9 preliminary evidence has already been obtained? ${ }^{\text {, may }}$ also be proposed. Evidence supporting these views may be derived from the fact that cerebron sulphate, in which the sulphate group has been assigned to position 6 of the galactose moiety ${ }^{8}$, also exhibits the $820 \mathrm{~cm} .^{-1}$ band. Consequently, the proposed correlation between the $820 \mathrm{~cm} .^{-1}$ band of chondroitin sulphate $C$, and substitution of the 6 (equatorial) position of galactosamine residues in this polymer is well supported.

The establishment of the sulphate group on the 4 (axial) position of galactosamine in chondroitin sulphate $B$ by methylation studies ${ }^{9}$, supports the assignment of the $850 \mathrm{~cm}^{-1}$ band to sulphation of position 4 of the hexosamine moiety of this compound, and, by analogy, of chondroitin sulphate $A$. Additional evidence in favour of these postulates is obtained from the appearance of the $850 \mathrm{~cm} .^{-1}$ band in spectra of Chondrus ocellatus mucilage polysaccharide (gift from Prof. T. Mori), and carrageenin (gift from Dr. F. A. Rose), in which the sulphate group has been established as being on position 4 of galactose by methylation studies 10 .

This work has been supported in part by a grant and Fellowship to A. G. Lloyd from the Empire Rheumatism Council and, in part, by a grant $(A 1982)$ to K. S. Dodgson from the Arthritis and Metabolic Diseases Division of the U.S. Public Health Service. A more complete account of these and other observations is in the course of preparation.

A. G. Lloyd

K. S. Dodgson

Department of Biochemistry,

University College,

Newport Road,

Cardiff.

June 29.

1 Orr, \&. F. D., Eiochim. Biophys. Acta, 14. $173(1954)$

2 Naganishi, K., Takahashi, N., and Egami, F. Bull. Chem. soc. Japan, 29, 434 (1956).

- Hoffman, P.. Linker, A., and Meyer, K., Biochim. Biophys. Actu, 20, 184 (1958)

Karitor, T. G., aud Schubert, M., J. Amer. Chem. Soc., 79, 15: (1956).

6 loodgson, K S, and Lloyd, A. G., Biochom, $J, 68,88$ (1958).

? Lloyd, A. G., Nature, 183, 109 (19j9)

Q Thannhauser, S. J., Fellig, J., and Schmidt, G., J. Biol. Chem., 215 $211(1955)$

Jeanloz, R. W., Stoffyn, P. J., and Tremege, M., Fed. Proc, 16, 20 (1957). Jeanloz, R. W, and Stoffyn, P. J, ibit, 17, 249 (1958)

1s Buchanan, J., Percival, E. E., and Percival, E. G. V., f. Chem. Sor. 51 (1943). Dewar, E. '1., ani Percival, E. G. V., J. Chem. Sor., 162. (1947).

\section{Interference by Azide with Diazotization Procedures used in Biological Assay Systems}

WHEN sodium azide $\left(5 \times 10^{-3} M\right)$ was added as an inhibitor of nitro-reductase activity of a Nocardia $s p$. using $p$-dinitrobenzene as substrate we were unable to detect the formation of $p$-nitroaniline by means of a diazotization assay ${ }^{1}$ although the appearance of a yellow colour indicated its formation. However, after extracting the reaction mixture with ether it was possible to show electrophoretically the presence of $p$-nitroaniline in the ether extract and that sodium azide at the above concentration has no inhibitory effect on the nitro-reductase systern.
We later studied the effect of sodium azide on the $p$-nitroaniline assay system using known concentrations of arylamine compounds. To a series of $15 \mathrm{ml}$. centrifuge tubes containing $10 \mu \mathrm{gm}$. of either $p$-aminobenzoic acid or $p$-nitroaniline, plus various concentrations of sodium azide, in a total volume of $2 \mathrm{ml}$. of distilled water, were added at room temperature $0.5 \mathrm{ml}$. $N$-hydrothloric acid and $0.25 \mathrm{ml}$. aqueous sodium nitrite $(0 \cdot 1$ per cent $\mathrm{w} / \mathrm{v})$. After $5 \mathrm{~min} .0 .25 \mathrm{ml}$. ammonium sulphamate $(0.5$ per cent w/v.) was added and thoroughly mixed. Three minutes later $0.25 \mathrm{ml}$. of $N$-(l-naphthyl)-ethylenediamine hydrochloride $(0 \cdot 1$ per cent $\mathrm{w} / \mathrm{v}$.) was added. After $30 \mathrm{~min}$. at room temperature the optical density of the solution was estimated at $540 \mathrm{~m} \mu$ using the Beckman model $D U$ spectrophotometer. The results (Table 1) demonstrate a marked inhibitory effect. of sodium azide on the diazotization reaction.

Table 1. Erfect of Sodiug Azide on Drazotization Reactions

\begin{tabular}{|c|c|c|c|c|}
\hline \multirow{3}{*}{$\begin{array}{l}\text { Concentration } \\
\text { of sodium } \\
\text { azide added } \\
(M)\end{array}$} & \multirow{2}{*}{\multicolumn{4}{|c|}{$\begin{array}{l}\text { Colour formation with : } \\
p \text {-Aminobenzoic acid } \quad p \text {-Nitroaniline }\end{array}$}} \\
\hline & & & & \\
\hline & $\begin{array}{l}\text { Optical } \\
\text { density } \\
\text { at } 540 \mathrm{~m} \mu\end{array}$ & $\underset{\text { (per cent) }}{\text { Inhibition }}$ & $\begin{array}{c}\text { Optical } \\
\text { density } \\
\text { at } 540 \mathrm{~m} \mu\end{array}$ & $\begin{array}{l}\text { Inhibition } \\
\text { (per cent) }\end{array}$ \\
\hline None & 1.030 & - & $1 \cdot 200$ & - \\
\hline $1 \times 10^{-4}$ & 1.030 & $=$ & $\begin{array}{l}1.200 \\
1.176\end{array}$ & 2 \\
\hline $5 \times 10^{-4}$ & 0.824 & 20 & 0.804 & 33 \\
\hline $1 \times 10^{-3}$ & 0.402 & 61 & 0.372 & 69 \\
\hline $5 \times 10^{-3}$ & 0.082 & 92 & 0.010 & 100 \\
\hline $1 \times 10^{-2}$ & 0.010 & 100 & 0.010 & 100 \\
\hline
\end{tabular}

Sodium azide has been reported by many workers to inhibit the activities of several enzyme systems (nitrate and nitrite reductases, nitroethane oxidase, organic nitrate reductase, and nitroaryl reductases, among others) in which the diazotization reaction was used to determine the extent of the reaction. In the light of the findings reported here it might be of interest to reinvestigate the effect of sodium azide on these enzyme systems.

M.R.C. Unit for Chemical Microbiology,

J. R. Villanueva

Department of Biochemistry, University of Cambridge.

${ }^{1}$ Glazeo, A. J., Wolf, L. M., and Dill, W. A., Arch. Biochem., 23, 411 $(1949)$.

\section{Immunochemical Studies of Polypeptidyl Proteins and Synthetic Polypeptides}

THE polymerization of $\mathrm{N}$-carboxyamino-acid anhydrides $^{1}$ has made available synthetic polypeptides of high molecular weights which consist of a single polypeptide chain containing one type of amino-acid residue; copolymers of two or more different aminoacids; or multichain polypeptides. The molecular weights and some chemical and physical properties are similar to those of proteins.

It is also possible to link chemically synthetic polypeptides to protein molecules by initiating polymerization of $\mathbf{N}$-carboxyamino-acid anhydrides with proteins ${ }^{2}$, yielding modified or polypeptidyl proteins which are chemically very similar to the native protein. Because the antigenic character of proteins may be associated with their polypeptide structure, we have studied the immunological properties of polypeptidyl proteins and synthetic polypeptides ${ }^{3,4}$.

Preparations of bovine serum albumin modified by the addition of peptides of glutamic acid, lysine, leucine, or phenylalanine $e^{2}$ were strongly antigenic in 